are similar to those reported for other $\mathrm{AuCl}_{4}^{-}$anions $(2 \cdot 28 \AA)$.

\section{References}

Collman, J. P., Hoard, J. L., Kim, J., LANG, G. \& Reed, C. A. (1975). J. Am. Chem. Soc. 97, 2676-2681.

Fleischer, E. B. \& LAszlo, A. (1968). Inorg. Nucl. Chem. Lett. 5, 373-376.

Fleischer, E. B., Miller, C. K. \& Webb, L. E. (1964). J. Am. Chem. Soc. 86, 2342-2347.

International Tables for X-ray Crystallography (1974). Vol. IV. Birmingham: Kynoch Press. (Present distributor D. Reidel, Dordrecht, The Netherlands.)

KirNer, J. F., ReEd, C. A. \& Scheidt, W. R. (1977). J. $A m$. Chem. Soc. 99, 1093-1101.
MADURA, P. \& SCHEIDT, W. R. (1976). Inorg. Chem. 15, 3182-3184

MELNIK, M. \& PARISH, R. V. (1986). Coord. Chem. Rev. 70, 157-257.

SCHEIDT, W. R. (1977). Acc. Chem. Res. 10, 339-345.

SCheidT, W. R., KASTNER, M. E. \& Hatano, K. (1978). Inorg. Chem. 17, 706-710.

Scheidt, W. R., Mondal, J. U., Eigenbrot, C. W., Adler, A., RADANOVICH, L. J. \& HOARD, J. L. (1986). Inorg. Chem. 25, 795-799.

SCHEIDT, W. R. \& REED, C. A. (1978). Inorg. Chem. 17, 710-714.

SHELDRICK, G. M. (1985). SHELXTL Users Manual, version 5.1. Nicolet XRD Corporation, Madison, Wisconsin, USA.

Stout, G. H. \& JENSEN, L. H. (1968). X-ray Structure Determination. Toronto: MacMillan.

Timkovich, R. \& Tulinsky, A. (1977). Inorg. Chem. 16, 962-963.

Acta Cryst. (1987). C43, 1878-1880

\title{
Structure of Dichloro[1,2-bis(diphenylphosphino)ethane]nickel(II) Dichloromethane Solvate
}

\author{
By A. L. SpeK* AND B. P. van EIJCK \\ Vakgroep Algemene Chemie, afdeling Kristal-en Structuurchemie, University of Utrecht, Padualaan 8, \\ $3584 \mathrm{CH}$ Utrecht, The Netherlands \\ AND R. J. F. JANS AND G. vAN KoTEN \\ Laboratorium voor Anorganische Chemie, University of Amsterdam, Nieuwe Achtergracht 166, \\ 1018 WV Amsterdam, The Netherlands
}

(Received 24 February 1987; accepted 12 May 1987)

\begin{abstract}
NiCl}_{2}\left(\mathrm{C}_{26} \mathrm{H}_{24} \mathrm{P}_{2}\right)\right] . \mathrm{CH}_{2} \mathrm{Cl}_{2}, \quad M_{r}=612.95$, monoclinic, $P 2_{1} / c, a=12.248$ (3), $b=15.388$ (3), $c$ $=15.290$ (4) $\AA, \beta=104.77(2)^{\circ}, U=2787(1) \AA^{3}, Z$ $=4, D_{x}=1.461 \mathrm{~g} \mathrm{~cm}^{-3}$, Mo $K \alpha, \lambda=0.71073 \AA$, $\mu$ $=12.1 \mathrm{~cm}^{-1}, F(000)=1256, T=295 \mathrm{~K}, R=0.056$ for 3610 observed reflections with $I>2 \cdot 5 \sigma(l)$. The square-planar geometry about $\mathrm{Ni}$ is defined by the two $\mathrm{P}$ and two $\mathrm{Cl}$ atoms to which it is bonded. The $\mathrm{P}-\mathrm{Ni}-\mathrm{P}$ bite angle of the chelating $\mathrm{Ph}_{2} \mathrm{PCH}_{2} \mathrm{CH}_{2} \mathrm{PPh}_{2}$ ligand is $86.93(6)^{\circ}$ and the $\mathrm{Cl}-\mathrm{Ni}-\mathrm{Cl}$ angle is $95.47(6)^{\circ}$. Distances to the coordinating ligands are $\mathrm{Ni}-\mathrm{Cl}$ 2.205 (2) and 2.195(2) $\AA$, Ni-P 2.157(2) and $2 \cdot 145(2) \AA$.
\end{abstract}

Introduction. In the course of investigations on the coordinating properties of chlorosulfine ligands, it was shown that metals can insert into the $\mathrm{C}-\mathrm{Cl}$ bond of the chlorosulfine (Alper, 1975; Gosselink, van Koten, Vrieze, Zwanenburg \& Lammerink, 1979; Gotzfried \& Beck, 1980; Gosselink, Brouwers, van Koten \& Vrieze, 1982; Gosselink, Bulthuis \& van Koten, 1982). We have

* Author to whom correspondence should be addressed. $0108-2701 / 87 / 101878-03 \$ 01.50$ examined the reaction of chlorosulfines with nickelbis(1,5-cyclooctadiene) in the presence of 1,2-bis(diphenylphosphino)ethane (dppe). The initial adduct of the chlorosulfine with the nickel dppe species readily decomposes to $\mathrm{NiCl}_{2} \mathrm{dppe}$, the crystal structure of which is presented here.

Experimental. Orange-brown crystal $(0.20 \times 0.20 \times$ $0.50 \mathrm{~mm}$ ) glued on top of a glass fiber with the longest dimension approximately parallel to the $\varphi$ axis. EnrafNonius CAD-4F diffractometer, $\mathrm{Zr}$-filtered Mo $K \alpha$ radiation. 8436 reflections scanned, $\omega / 2 \theta$ scan; $\Delta \omega$ $=(0.60+0.35 \tan \theta)^{\circ} ; 1.33<\theta<30.0^{\circ} ; h-17 \rightarrow 16$, $k 0 \rightarrow 21, l 0 \rightarrow 21$. Three reference reflections (504: e.s.d. $0.8 \% ; \overline{4} \overline{6} 3$ : e.s.d. $0.8 \% ; \overline{3} 46$ : e.s.d. $0.8 \%$ ); linear decay of $16 \%$ during $140 \mathrm{~h}$ of $\mathrm{X}$-ray exposure time. Cell dimensions from the setting angles of 16 reflections $\left(10<\theta<11.5^{\circ}\right)$. Space group $P 2_{1} / c$ from the observed extinctions ( $0 k 0: k=2 n+1 ; h 0 l: l=2 n+1)$. Correction for $\mathrm{Lp}$ and linear decay but not for absorption. [A $360^{\circ} \psi$ scan for the close to axial reflection $0 \overline{1} 3$ did not show a variation higher than $6 \%$ in the intensity.] 8108 unique reflections of which c 1987 International Union of Crystallography 
Table 1. Final atomic coordinates and equivalent isotropic thermal parameters for the non- $\mathrm{H}$ atoms

\begin{tabular}{lcccc}
\multicolumn{5}{c}{$U_{\text {eq }}=\frac{1}{3} \sum_{i} \sum_{j} U_{i j} a_{i}^{*} a_{j}^{*} \mathbf{a}_{i} \cdot \mathbf{a}_{j} \cdot$} \\
& $x$ & $y$ & $z$ & $U_{\text {ca }}\left(\AA^{2}\right)$ \\
$\mathrm{Ni}$ & $0.22056(5)$ & $0.19661(4)$ & $0.37344(4)$ & $0.0359(2)$ \\
$\mathrm{Cl}(1)$ & $0.3097(1)$ & $0.1358(1)$ & $0.2808(1)$ & $0.0556(5)$ \\
$\mathrm{Cl}(2)$ & $0.0539(1)$ & $0.1435(1)$ & $0.3063(1)$ & $0.0531(5)$ \\
$\mathrm{P}(1)$ & $0.1448(1)$ & $0.2639(1)$ & $0.4669(1)$ & $0.0367(4)$ \\
$\mathrm{P}(2)$ & $0.3792(1)$ & $0.2477(1)$ & $0.4498(1)$ & $0.0410(4)$ \\
$\mathrm{C}(1)$ & $0.2478(4)$ & $0.3386(3)$ & $0.5358(3)$ & $0.044(2)$ \\
$\mathrm{C}(2)$ & $0.3616(4)$ & $0.2926(3)$ & $0.5569(3)$ & $0.046(2)$ \\
$\mathrm{C}(11)$ & $0.1096(3)$ & $0.1887(3)$ & $0.5464(3)$ & $0.039(2)$ \\
$\mathrm{C}(12)$ & $0.0194(4)$ & $0.3292(3)$ & $0.4231(3)$ & $0.039(2)$ \\
$\mathrm{C}(13)$ & $0.5002(4)$ & $0.1766(3)$ & $0.4828(3)$ & $0.050(2)$ \\
$\mathrm{C}(14)$ & $0.4227(4)$ & $0.3394(3)$ & $0.3929(3)$ & $0.043(2)$ \\
$\mathrm{C}(21)$ & $0.0681(4)$ & $0.2187(3)$ & $0.6172(3)$ & $0.053(2)$ \\
$\mathrm{C}(22)$ & $0.0310(5)$ & $0.4152(3)$ & $0.3980(3)$ & $0.057(2)$ \\
$\mathrm{C}(23)$ & $0.5106(6)$ & $0.1213(4)$ & $0.5564(4)$ & $0.086(3)$ \\
$\mathrm{C}(24)$ & $0.5171(4)$ & $0.3884(3)$ & $0.4353(3)$ & $0.061(2)$ \\
$\mathrm{C}(31)$ & $0.0391(5)$ & $0.1599(4)$ & $0.6761(3)$ & $0.064(2)$ \\
$\mathrm{C}(32)$ & $-0.0653(6)$ & $0.4644(4)$ & $0.3605(4)$ & $0.073(3)$ \\
$\mathrm{C}(33)$ & $0.6030(8)$ & $0.0695(5)$ & $0.5848(4)$ & $0.114(4)$ \\
$\mathrm{C}(34)$ & $0.5511(5)$ & $0.4568(4)$ & $0.3921(4)$ & $0.073(3)$ \\
$\mathrm{C}(41)$ & $0.0534(5)$ & $0.0723(4)$ & $0.6667(4)$ & $0.066(2)$ \\
$\mathrm{C}(42)$ & $-0.1695(5)$ & $0.4287(5)$ & $0.3475(4)$ & $0.075(3)$ \\
$\mathrm{C}(43)$ & $0.6870(6)$ & $0.0710(5)$ & $0.5426(6)$ & $0.117(4)$ \\
$\mathrm{C}(44)$ & $0.4908(6)$ & $0.4801(4)$ & $0.3070(5)$ & $0.081(3)$ \\
$\mathrm{C}(51)$ & $0.0968(5)$ & $0.0429(4)$ & $0.5985(3)$ & $0.072(2)$ \\
$\mathrm{C}(52)$ & $-0.1816(5)$ & $0.3452(5)$ & $0.3716(4)$ & $0.084(3)$ \\
$\mathrm{C}(53)$ & $0.6756(6)$ & $0.1223(5)$ & $0.4658(6)$ & $0.118(4)$ \\
$\mathrm{C}(54)$ & $0.3964(6)$ & $0.4341(4)$ & $0.2640(4)$ & $0.079(3)$ \\
$\mathrm{C}(61)$ & $0.1240(4)$ & $0.1003(3)$ & $0.5375(3)$ & $0.058(2)$ \\
$\mathrm{C}(62)$ & $-0.0869(4)$ & $0.2949(3)$ & $0.4095(3)$ & $0.063(2)$ \\
$\mathrm{C}(63)$ & $0.5826(5)$ & $0.1747(4)$ & $0.4376(4)$ & $0.084(3)$ \\
$\mathrm{C}(64)$ & $0.3617(4)$ & $0.3628(3)$ & $0.3065(3)$ & $0.058(2)$ \\
$\mathrm{CH}{ }_{2} \mathrm{Cl}{ }_{2}{ }_{2}$ solvate & & & & \\
$\mathrm{Cl}(3)$ & $0.6605(2)$ & $0.1850(2)$ & $0.2104(2)$ & $0.174(1)$ \\
$\mathrm{Cl}(4)$ & $0.7983(2)$ & $0.1208(2)$ & $0.1000(2)$ & $0.199(2)$ \\
$\mathrm{C}(3)$ & $0.7742(6)$ & $0.1892(8)$ & $0.1780(6)$ & $0.216(8)$ \\
& & & &
\end{tabular}

4498 with $I<2.5 \sigma(I)$ were observed. The structure was solved by standard Patterson and Fourier methods and refined by full-matrix least-squares techniques on $F$ with anisotropic thermal parameters for the non- $\mathrm{H}$ atoms. $\mathbf{H}$ atoms were included on calculated positions $[d(\mathrm{C}-\mathrm{H})=1.08 \AA]$ with fixed isotropic thermal parameters $\left(U=0.08 \AA^{2}\right)$. Convergence was reached at $R=$ $0.056\left[w R=0.042 ; w=1 / \sigma^{2}(F) ; S=1.84 ;(\Delta / \sigma)_{\max }\right.$ $=0.3]$ for 3610 observed reflections $[I>2.5 \sigma(I)]$ and 308 parameters. Residual density range: 0.87 (near $\mathrm{Ni})$ and $-0.71 \mathrm{e} \AA^{-3}$. Scattering factors from Cromer \& Mann (1968) and anomalous-dispersion corrections from Cromer \& Liberman (1970). Calculations carried out on the Cyber-855 of the University of Utrecht with programs of the SHELX76 (Sheldrick, 1976) and EUCLID (Spek, 1982) packages.

Discussion. Final atomic parameters are given in Table $1^{*}$ and derived bond distances, bond angles and torsion angles in Table 2. Fig. 1 illustrates the molecular

* Lists of structure factors, anisotropic thermal parameters, $\mathrm{H}$-atom parameters and complete lists of bond lengths and bond angles have been deposited with the British Library Document Supply Centre as Supplementary Publication No. SUP 44049 (26 pp.). Copies may be obtained through The Executive Secretary, International Union of Crystallography, 5 Abbey Square, Chester $\mathrm{CH} 12 \mathrm{HU}$, England.
Table 2. Selected bond distances $(\AA)$, angles $\left(^{\circ}\right)$ and torsion angles $\left(^{\circ}\right)$ for the non- $\mathrm{H}$ atoms

\begin{tabular}{|c|c|c|c|}
\hline $\mathrm{Ni}-\mathrm{Cl}(\mathrm{I})$ & $2 \cdot 205(2)$ & $C(14)-C(64)$ & $1 \cdot 389(6)$ \\
\hline $\mathrm{Ni}-\mathrm{Cl}(2)$ & $2.195(2)$ & $C(21)-C(31)$ & $1 \cdot 385(7)$ \\
\hline $\mathrm{Ni}-\mathrm{P}(1)$ & $2 \cdot 157(2)$ & $C(22)-C(32)$ & $1.396(9)$ \\
\hline $\mathrm{Ni}-\mathrm{P}(2)$ & $2 \cdot 145(2)$ & $C(23)-C(33)$ & $1.36(1)$ \\
\hline$P(1)-C(1)$ & $1.829(5)$ & $C(24)-C(34)$ & $1 \cdot 363(8)$ \\
\hline$P(1)-C(11)$ & $1.808(5)$ & $C(31)-C(41)$ & $1.372(9)$ \\
\hline$P(1)-C(12)$ & $1.815(5)$ & $C(32)-C(42)$ & $1 \cdot 36(1)$ \\
\hline$P(2)-C(2)$ & $1.840(5)$ & $C(33)-C(43)$ & $1 \cdot 35(1)$ \\
\hline$P(2)-C(13)$ & $1.807(5)$ & $C(34)-C(44)$ & $1.370(9)$ \\
\hline$P(2)-C(14)$ & $1.808(5)$ & $C(41)-C(51)$ & $1.363(8)$ \\
\hline$C(1)-C(2)$ & $1.523(7)$ & $C(42)-C(52)$ & $1 \cdot 36(1)$ \\
\hline$C(11)-C(21)$ & $1 \cdot 387(6)$ & $C(43)-C(53)$ & $1.39(1)$ \\
\hline$C(11)-C(61)$ & $1.383(7)$ & $C(44)-C(54)$ & $1 \cdot 37(1)$ \\
\hline$C(12)-C(22)$ & $1.395(7)$ & $C(5 I)-C(61)$ & $1.385(7)$ \\
\hline$C(12)-C(62)$ & $1.371(7)$ & $C(52)-C(62)$ & $1.392(8)$ \\
\hline$C(13)-C(23)$ & $1.391(8)$ & $C(53)-C(63)$ & $1 \cdot 37(1)$ \\
\hline$C(13)-C(63)$ & $1.361(8)$ & $C(54)-C(64)$ & $1.396(8)$ \\
\hline$C(14)-C(24)$ & $1 \cdot 394(7)$ & & \\
\hline $\mathrm{Cl}(1)-\mathrm{Ni}-\mathrm{Cl}(2)$ & $95.47(6)$ & $C(1)-P(1)-C(12)$ & $105 \cdot 0(2)$ \\
\hline $\mathrm{Cl}(1)-\mathrm{Ni}-\mathrm{P}(1)$ & $175 \cdot 19(6)$ & $C(11)-P(1)-C(12)$ & $106 \cdot 1(2)$ \\
\hline $\mathrm{Cl}(1)-\mathrm{Ni}-\mathrm{P}(2)$ & $88.68(6)$ & $\mathrm{Ni}-\mathrm{P}(2)-\mathrm{C}(2)$ & $109 \cdot 1(2)$ \\
\hline $\mathrm{Cl}(2)-\mathrm{Ni}-\mathrm{P}(1)$ & $89.01(6)$ & $\mathrm{Ni}-\mathrm{P}(2)-\mathrm{C}(13)$ & $119.6(2)$ \\
\hline $\mathrm{Cl}(2)-\mathrm{Ni}-\mathrm{P}(2)$ & $175.06(7)$ & $\mathrm{Ni}-\mathrm{P}(2)-\mathrm{C}(14)$ & $111 \cdot 2(2)$ \\
\hline $\mathrm{P}(1)-\mathrm{Ni}-\mathrm{P}(2)$ & $86.93(6)$ & $C(2)-P(2)-C(13)$ & $104 \cdot 6(2)$ \\
\hline $\mathrm{Ni}-\mathrm{P}(1)-\mathrm{C}(1)$ & $109 \cdot 5(2)$ & $C(2)-P(2)-C(14)$ & $104 \cdot 5(2)$ \\
\hline $\mathrm{Ni}-\mathrm{P}(1)-\mathrm{C}(11)$ & $110.8(2)$ & $C(13)-P(2)-C(14)$ & $106 \cdot 6(2)$ \\
\hline $\mathrm{Ni}-\mathrm{P}(1)-\mathrm{C}(12)$ & $119 \cdot 2(2)$ & $P(1)-C(1)-C(2)$ & $106 \cdot 8(3)$ \\
\hline$C(1)-P(1)-C(11)$ & $105 \cdot 2(2)$ & $P(2)-C(2)-C(1)$ & $107 \cdot 1(3)$ \\
\hline $\begin{array}{l}C(64)-C(14)-P \\
C(63)-C(13)-P\end{array}$ & $\begin{array}{r}-6 \cdot 3(4) \\
-26 \cdot 3(5)\end{array}$ & $C(61)-C(11)$ & $-5 \cdot 0(4)$ \\
\hline
\end{tabular}

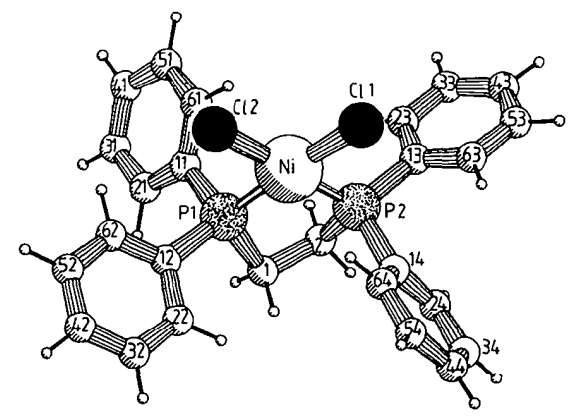

Fig. 1. Drawing of the molecule with numbering scheme.

geometry and the atom numbering. The unit cell contains four molecules of the $\mathrm{Ni}$ complex and four $\mathrm{CH}_{2} \mathrm{Cl}_{2}$ molecules of crystallization that are separated by normal van der Waals distances. The molecule has approximate noncrystallographic twofold axial symmetry. The coordination geometry about $\mathrm{Ni}$ is essentially square planar although slightly distorted in the direction of tetrahedral [as may be seen from the trans ligand bond angle values $\mathrm{Cl}(1)-\mathrm{Ni}-\mathrm{P}(1) 175 \cdot 19$ (7) and $\left.\mathrm{Cl}(2)-\mathrm{Ni}-\mathrm{P}(2) 175.06(6)^{\circ}\right]$ with the central atom displaced only 0.008 (4) $\AA$ from the least-squares plane defined by the $\mathrm{P}$ and $\mathrm{Cl}$ atoms to which it is bonded. The present structure resembles that of the related structure of $\mathrm{Ni}\left(\mathrm{NO}_{2}\right)_{2}$ dppe. $\mathrm{CH}_{2} \mathrm{Cl}_{2}$ (Kriege-Simondsen \& Feltham, 1983). The Ni-P(1) [2.157(2) $\AA]$ and $\mathrm{Ni}-\mathrm{P}(2)[2 \cdot 145(2) \AA]$ distances in the $\mathrm{Cl}$ compound are significantly shorter than the corresponding values $[2.178(3)$ and $2.182(4) \AA]$ in the $\mathrm{NO}_{2}$ complex. The 
title compound is isomorphous with the related $\mathrm{Pd}$ compound (Steffen \& Palenik, 1976). The overall geometry of both compounds is the same: the major difference stems from shorter $\mathrm{Ni}-\mathrm{P}$ and $\mathrm{Ni}-\mathrm{Cl}$ distances $(0.08$ and $0.06 \AA$ respectively).

The investigations were supported in part (ALS) by the Netherlands Foundation for Chemical Research (SON) with financial aid from the Netherlands Organization for the Advancement of Pure Research (ZWO).

\section{References}

Alper, H. (1975). J. Organomet. Chem. 84, 347-350.

Cromer, D. T. \& Liberman, D. (1970). J. Chem. Phys. 53, 1891-1898.
Cromer, D. T. \& MANN, J. B. (1968). Acta Cryst. A24, 321-324.

Gosselink, J. W., Brouwers, A. M. F., van Koten, G. \& VRIEZE, K. (1982). J. Chem. Soc. Dalton Trans. pp. 397-406.

Gosselink, J. W., Bulthuis, H. \& van Koten, G. (1982). J. Chem. Soc. Dalton Trans. pp. 1342-1348.

Gosselink, J. W., van Koten, G., VRIeze, K., Zwanenburg, B. \& LAMMERINK, B. H. M. (1979). J. Organomet. Chem. 179, 411-419.

GotZFried, F. \& Веск, W. (1980). J. Organomet. Chem. 191, 329-338.

Kriege-Simondsen, J. \& Feltham, R. D. (1983). Inorg. Chim. Acta, 71, 185-194.

SHELDRICK, G. M. (1976). SHELX76. Program for crystal structure determination. Univ. of Cambridge, England.

SPEK, A. L. (1982). The EUCLID Package. In Computational Crystallography, edited by D. SAYRE, p. 528. Oxford: Clarendon Press.

Steffen, W. L. \& Palenik, G. J. (1976). Inorg. Chem. 15, 2432-2438.

Acta Cryst. (1987). C43, 1880-1882

\title{
Structure of (Acetato)dibromobis(triphenylphosphine)osmium(III)
}

\author{
By C. C. Hinckley, ${ }^{*}$ M. Matusz and P. A. Kibala \\ Department of Chemistry and Biochemistry, Southern Illinois University, Carbondale, IL 62901, USA
}

AND P. D. ROBINSON

Department of Geology, Southern Illinois University, Carbondale, IL 62901, USA

(Received 14 February 1987; accepted 13 May 1987)

\begin{abstract}
OsBr}_{2}\left(\mathrm{C}_{2} \mathrm{H}_{3} \mathrm{O}_{2}\right)\left\{\mathrm{P}\left(\mathrm{C}_{6} \mathrm{H}_{5}\right)_{3}\right\}_{2}\right], M_{r}=933.63$, monoclinic, $P 2_{1} / a, a=28.897(8), \quad b=14.106(5)$, $c=9.605$ (4) $\AA, \quad \beta=93.21(4)^{\circ}, V=3909$ (4) $\AA^{3}, Z$ $=4, D_{x}=1.59 \mathrm{~g} \mathrm{~cm}^{-3}$, Mo $K \alpha, \lambda=0.71069 \AA, \mu=$ $57.33 \mathrm{~cm}^{-1}, \quad F(000)=1812, T=295 \mathrm{~K}, R=0.046$, 3857 unique observed reflections. The complex was synthesized by refluxing an acetic acid/acetic anhydride solution containing $\mathrm{OsBr}_{6}^{2-}$, triphenylphosphine and sodium acetate. The central portion of the molecule contains a planar atomic array comprised of an Os atom bound to two cis $\mathrm{Br}$ atoms and a bidentate acetate ligand. Normal to the plane are two trans triphenylphosphine groups, bound to Os through their P atoms.
\end{abstract}

Introduction. (Acetato)dibromobis(triphenylphosphine)osmium(III) is an apparent member of a class of osmium complexes synthesized by Moore \& Robinson (1979) with general formula $\left[\mathrm{OsBr}_{2}\left(\mathrm{O}_{2} \mathrm{CR}\right)\left\{\mathrm{P}\left(\mathrm{C}_{6}\right.\right.\right.$ $\left.\left.\mathrm{H}_{5}\right)_{3}\right\}_{2}$ ], where $R$ is aryl. Their preparation involved the air oxidation of $\left[\mathrm{OsBr}_{2}\left\{\mathrm{P}\left(\mathrm{C}_{6} \mathrm{H}_{5}\right)_{3}\right\}_{3}\right]$ in the presence of the appropriate carboxylic acid. IR spectra indicated chelated arylcarboxylic ligands; a trans placement of

* Author to whom correspondence should be addressed.

0108-2701/87/101880-03\$01.50 the $\mathrm{Br}$ ligands was proposed. The title compound was prepared in solution by reduction of the hexabromoosmate(IV) ion, $\mathrm{OsBr}_{6}^{2-}$. The structure determination confirms the chelated binding of the carboxylate ligand, but the $\mathrm{Br}$ ligands are cis rather than trans.

Experimental. Preparation by dissolution of bis(tetra$n$-butylammonium)hexabromoosmate(IV) $\quad(1.0 \mathrm{~g}$, $0.87 \mathrm{mmol})$, triphenylphosphine $(1.0 \mathrm{~g}, 3.8 \mathrm{mmol})$ and sodium acetate trihydrate $(2.0 \mathrm{~g}, 14.7 \mathrm{mmol})$ in a mixture of $20.0 \mathrm{ml}$ acetic acid and $20.0 \mathrm{ml}$ acetic anhydride. Mixture refluxed for $10 \mathrm{~min}$ during which time yellow crystals appeared. Mixture cooled, filtered, and the solid washed with acetic acid and chilled ethyl ether (yield $0.68 \mathrm{~g}$ ). Crystals obtained by dissolving the solid in dichloromethane and layering with $n$-hexane.

Crystal used for data collection was $0.21 \times 0.11 \times$ $0.05 \mathrm{~mm}$, brown, bladed. Rigaku AFC5S diffractometer, graphite-monochromatized Mo $K \alpha$ radiation, $\omega-2 \theta$ scans, scan speed $6^{\circ} \mathrm{min}^{-1}$, maximum of 3 scan repetitions to obtain $\sigma F / F<0 \cdot 10$. Lattice parameters from least-squares fit of 16 reflections in $2 \theta$ range $9-22^{\circ} .7672$ reflections measured $(h-34$ to $34, k 0$ to $16, l 0$ to 11$) ; 7212$ reflections unique, 3857 observed (C) 1987 International Union of Crystallography 